\title{
INFLUENCE OF INCOME ON TERTIARY STUDENTS ACQUISITION OF CELLULAR PRODUCTS
}

GAP Drotsky, B Janse van Rensburg \& JW de Jager, Tshwane University of Technology, Pretoria, South Africa

Purpose: The purpose of the article is to determine whether there are any differences between high and low-income group
students in their selection of a cellular phone brand or network operator.

Design / Methodology / Approach: Four hypotheses are set to determine if there are any significant differences between the two income groups in current decision-making. It is established that there exist no significant difference between high and low-income students in their selection of cellular phones and network operators. The levels of agreement or disagreement on various statements do, however, give an indication of the importance that students place on aspects that they view as important when acquiring a cellular phone or network operator.

Findings: In the article, it is established that no significant differences exist between the two income groups. The levels of agreement or disagreement indicate the importance that subscription method, social value, service quality and branding has on student decision-making.

Implications: The article provides a better understanding of the influence that income plays in student's decision-making in acquiring cellular products and services. Possible future research in student cellular usage can be guided through the information obtained in this article.

Originality / Value: The article provides information to cellular network operators, service providers and cellular phone manufactures regarding the influence of income on students' acquisition of cellular products and services. Information from the article can assist in the establishment of marketing plans for the student market by these role players.

Key words and phrases: Cellular phones, network operators, students, income.

\section{INTRODUCTION}

In South Africa it is not uncommon to see people from different walks of life with a cellular phone (Cant \& Machado, 2005:3). Morhange and Fontela (2003:25) indicate that cellular phones changed all aspects of consumers' lifestyles. Cellular phones are not seen as luxury for the selected few, but have become a necessity for every person and obtained for different reasons that include: to do business; safety; or just to stay in contact with friends and family (Mutula, 2002:79-92). An influence on the acquisition of cellular products and services is a consumer's disposable income. Personal disposable income is the amount of money that consumers have available after all fixed obligations have been met. This can then be used to purchase consumer products and services.

The population for this article is full-time students. This means that they, in the majority of cases, do not work, but rely on their families, bursaries or part time jobs for an income, thus restricting their disposable income. Price is thus very important to students and, as indicated by research done by Martin and Marshall (1999:206-218) on the influence of low and high involvement advertising in the cellular market, price is more important to students than the images created by advertising. Although students want to purchase the advertised cellular products, they do not have the income to do so. Irrespective, status plays an important role and students acquire cellular phones to enhance their status. As indicated by Claasen (2001:1), consumers are spending more money on cellular phones than on clothing. Although the level of income of a consumer also indicates his or her social status in a society (Schiffman \& Kanuk, 2000:298), ownership to a student is an indication of status far more than disposable income. They then also tend to 
spend a substantial portion of their available income on cellular phones and services (Srivastava, 2004:250).

As students represent a sizeable segment of the market, the cellular industry should take note of students' attitudes, behaviour and spending with regards to cellular products. In South Africa, approximately 600000 students enrol at tertiary institutions annually (UNESCO, 1998).

Firstly, in this article, a literature review is given on consumption behaviour, influence of income, student's behaviour and price strategies that are followed in the cellular telecommunication market. Secondly, the research methodology is discussed including researcher design, sample composition, the hypotheses set, and the test used in the article. The levels of agreement or disagreement on a seven point Likert scale is then discussed in more detail. Lastly, the conclusions and recommendations are made.

\section{CONCEPTS AND LITERATURE REVIEW}

A society can be divided into different social classes. These are mostly based on income, but a consumer's occupation, dress, speech and recreation can also be a determinant of social standing. A typical characteristic of social class is that people from the same social class behave in the same way. Furthermore, social classes are divided into superior and inferior groups, but a person can migrate between different social class levels (Kotler, 2003:184). Cant, Brink and Brijball (2006:78) state that cellular phones are status symbols for consumers. Therefore, it can be assumed that, in making a decision regarding which cellular phone to acquire, students will consider the social impact of such as decision. The social class that students are part of gives rise to a specific lifestyle or way of living. Schiffman and Kanuk, (2004:408) point out that culture can be viewed as a lifestyle.

Solomon (2004:498) states that two subcultures can be identified in culture, namely age and gender, and indicates that these two subcultures have an influence on consumers' decision-making processes. Age and gender are discussed in more detail, as they are especially relevant to students' acquisition of cellular phones and services.

According to Cant et al. (2002:86), there are different reasons why age is important to marketers. Therefore, it is necessary to identify different age groups. Arnould, Price and Zinkhan (2004:502) differentiate between age groups by dividing people according to specific time periods and identify the following groups: millennials, baby boomers, generation $X$ and Generation $Y$. Generation $Y$ is described by Solomon (2004:500) as children born between 1977 and 1994. As the majority of students fall into this group, the characteristics of generation $Y$ (teenagers) will be discussed in more detail. Martin and Bush (2000:441) indicate that members of generation $Y$ are more involved in setting trends than any other age group and that they set trends for the population at large.

Age has an important influence on the products that consumers purchase. Younger people are becoming more independent. They have their own values and demands that may differ from those of their families and friends. Laroche, Saad, Cleveland and Brown (2000:502) point out that young consumers should be taken into account when explaining household decision-making. As Cant et al. (2002:91) indicate, Generation $Y$ children are more sophisticated in decision-making. They shop extensively for good value, which causes them to be more selective about how they spend their money. Solomon (2004:501) states that teenagers are individuals who are leaving the role of children and preparing to assume the role of adults. Selian (2004:5) indicates that the youth need to assert their individuality and that young people buy products that are status symbols that will help them fit in with their peer groups to conform to peer pressure. Joubert (2000:1) states that the cellular phone is no longer just an instrument for communicating or for safety, but has become a must-have fashion accessory for millions. Spero and Stone (2004:159) indicate that teenagers will not buy products that do not fit in with or enhance their lifestyle. Srivastava (2004:250) states that, in countries like Japan, the gap between younger and older generations in terms of cellular phone ownership is narrowing and that young people have higher cellular 
telephone bills than older people. There is currently no indication that this is true for South Africa, although this study will provide an indication of students' spending on cellular phones and services.

The second sub-cultural element of importance is gender. Gilbert, Kelly and Barton (2003:254) refer to "technophobia", the anxiety or negative attitude toward using technology, and that it is a factor to consider when examining the adoption of technological products, especially in the case of female consumers. Ward and Sturrock (1998:332) state that, when selecting products, females want highly practical products and prefer to take someone along when making a purchase. Selian (2004:30) indicates that males and females have many perceptions and habits in common and, although they differ in their preference of colour and accessories, they fundamentally use cellular phones for the same reasons. However, there are differences in usage of cellular phones. Reid and Reid (2004:200) indicate that younger females use SMS's more as a way of maintaining friendships than male cellular phone users. Srivastava (2004:250) indicates that teenage girls have an impact on the design of cellular text messages and cellular phone emails. Bakewell and Mitchell (2003:103) indicate that, for Generation Y females, the one key element when shopping for products is enjoyment and the leisurely shopping experience. Backwell and Mitchell (2003:103-104) state that Generation Y females will not easily investigate or evaluate a brand if the brand is not already favoured. Vrechopoulos, Constantiou and Sideris (2002:4) point out that young males use their cellular phones for shopping purposes, whereas young females do not like this way of shopping. It is interesting to note that most of the young males who use their cellular phones for shopping have a matric certificate or university degree.

Due to students not working, the price of the cellular products and services can influence their decisions on what to acquire. The Economist (1999:2) indicates that the prices of cellular phones are falling and they are becoming more affordable than fixed lines. Minges, Männistö and Kelly (1999:491) state that the pre-paid cellular phone is becoming a mass market commodity and is no longer just for the wealthy. These authors indicate that pre-payment lowers the risk for network operators and that the cost of reaching such a consumer is also lower. Kshetri and Cheung (2002:25) refer to the importance of the introduction of pre-paid cards and that these cards are leading to the rapid diffusion of cellular phones across the world. According to The Economist (1999:1), even poor people are starting to use cellular phones by putting their money together and buying a cellular phone in groups. They buy pre-paid cards and, if the money runs out, they can still receive calls. Kress, Ozawa and Schmid (2000:6) state that consumers will switch to a lower-priced brand if they perceive it to be of better value. Selian (2004:8) indicates that young people prefer the pre-paid option since it gives them access to wireless services and allows them to get extra minutes beyond the basic security plan that their parents might pay. Price thus plays an important role in the cellular telecommunication industry.

Differences in lifestyle and consumption behaviour exist in different social classes in South Africa. Hawkins, Best and Coney (2001:137) indicate that different social classes will spend their income differently; individuals in the upper social class will not be price sensitive when buying products while the lower class will be more price-sensitive and will not easily spend disposable income on luxuries. Pakola, Pietilä, Svento and Karjaluoto (2003:4) indicate that price is one of the most important decision criteria when purchasing a cellular phone and it is also one of the reasons why cellular phone services are losing potential customers. Parker, Hermans and Schaefer (2004:176) confirm this and indicate that there are differences in the fashion choices where disposable income differs. Opposing this, Minges et al. (1999:491) indicate that cellular phones are becoming a mass-market commodity and are not just for the wealthy any more due to pre-paid vouchers. According to Selian (2004:8), young people prefer pre-paid packages because it gives them discretionary access to wireless services and it allows them to get extra minutes beyond the basic security plan that their parents might pay. Usage, however, remains a factor of disposable income and as students from different social classes behave in different ways, their income influences their acquisition of cellular products and the level of spending on such services. 


\section{RESEARCH METHODOLOGY}

\section{Research Design}

The study was completed in two phases. Firstly, a literature study was conducted on the different aspects that could influence students' acquisition of cellular products and services. Consumer behaviour elements that have an influence on the buying behaviour of consumers were evaluated as well as existing cellular phones and services and their pricing reviewed by means of the consultation of newspapers, magazines articles and research publications. Secondly, primary research was completed to test the hypotheses that were set for the study. Probability sampling and a self-administering questionnaire were used. The questionnaire was pre-coded and contained multiple and scale questions.

A descriptive research design was used that uses a set of scientific methods and procedures to collect raw data and create data calculations that describe the existing characteristics of a defined target population or market structure. Descriptive research attempts to obtain a complete and accurate description of the situation and determines the frequency with which something occurs (Hair, Bush \& Ortinau, 2000:38; Strydom, Joost \& Cant, 2000:152 and Churchill, 2001:46). Students studying at Tshwane University of Technology represented the survey population. The study population is the aggregate of elements from which the sample is actually selected and from this inferences can be made about the original population (Kinnear \& Taylor, 1996:411). In the study, a multi-stage cluster sampling method was used which consists of two or more steps in the selection of groups from the population that is broken down into sub-groups that are mutually exclusive and collectively exhaustive. Thereafter, a random sample of the groups was selected for further sampling (Dillon, Madden, \& Firtle, 1994:241). Full time students at pre-selected faculties of Tshwane University of Technology made up the sample frame. The eleven faculties at Tshwane University of Technology were listed and departments were selected from the faculties where after a simple random sample of students was drawn from each department. 430 questionnaires were distributed and, from the distributed questionnaires, 422 were received back. Of these, 410 were used. 12 questionnaires were rejected due to incompleteness.

\section{Sample Composition}

The final sample was composed of $53.17 \%$ female and $46.83 \%$ male respondents. $59.51 \%$ of the respondents receive an income of less than R500 (1 Rand $= \pm 6.5$ US \$) per month, with the remainder receiving more.

\section{Data Analysis}

\section{Hypotheses}

The following hypotheses were formulated:

$\mathrm{Ho}_{1}$ - Students with a monthly income up to R500 and monthly income of R501 and more attach the same preferences to pre-paid and contract.

$\mathrm{Ha}_{1}$ - Students with a monthly income up to R500 and monthly income of R501 and more do not attach the same preferences to pre-paid and contract.

$\mathrm{Ho}_{2}$ - Students with a monthly income up to R500 and monthly income of R501 and more attach the same status value to cellular phones.

$\mathrm{Ha}_{2}-$ Students with a monthly income up to R500 and monthly income of R501 and more do not attach the same status value to cellular phones.

$\mathrm{Ho}_{3}-$ Students' (with a monthly income up to R500 and monthly income of R501 and more) perception of the relationship between network operator and service quality is the same. 
$\mathrm{Ha}_{3}$ - Students' (with a monthly income up to R500 and monthly income of R501 and more) perception of the relationship between network operator and service quality is not the same

$\mathbf{H o}_{4}$ - Students' (with a monthly income up to R500 and monthly income of R501 and more) perception of the relationship between brand name and the quality of cellular phones is the same.

$\mathrm{Ha}_{4}$ - Students' (with a monthly income up to R500 and monthly income of R501 and more) perception of the relationship between brand name and the quality of cellular phones is not the same

t-Test

According to Malhotra (2004:448-450), a t-test is the most commonly used parametric test. A parametric test provides inferences for making statements about means of parent populations. Tustin, Ligthelm, Martins and Van Wyk. (2005:657) state that t-test is used to assess the significance of individual $b$ coefficients and specific testing the null hypothesis that the regression coefficient is zero. McDaniel and Gates (2005:487) indicate that the t-test is both appropriate for small samples $(n<30)$ and also theoretically correct for larger sample $(n \geq 30)$. The t-test produces two tests of the differences between the two groups; one test assumes that variances of the two groups are equal. Levene statistic tests this assumption and, if the value is greater than 0.10 , it can be assumed that the two groups have equal variance and the second test can be ignored.

For a better understanding of the analysed data, the levels of agreement and disagreement are discussed in table 1, table 2, table 3 and table 4.

Table 1: t-Test results for students' (with a monthly income up to R500 and monthly income of R501 and more) preference of pre-paid versus contract.

\begin{tabular}{|l|l|l|l|l|l|}
\hline \multirow{2}{*}{$\begin{array}{l}\text { Description of } \\
\text { variable }\end{array}$} & \multicolumn{2}{l|}{$\begin{array}{l}\text { Means } \\
(1: \text { Strongley disagree - } \\
7: \text { Strongley agree })\end{array}$} & $\begin{array}{l}\text { t-Test for Equality } \\
\text { of Means }\end{array}$ & $\begin{array}{l}\text { Hypotheses } \\
\text { testing }\end{array}$ \\
\cline { 2 - 5 } & $\begin{array}{l}\text { Below } \\
\text { R500 }\end{array}$ & $\begin{array}{l}\text { Above } \\
\text { R501 }\end{array}$ & t & Sig. & \\
\hline $\begin{array}{l}\text { V37 } \\
\text { Price influences my } \\
\text { choice between pre- } \\
\text { paid vouchers and } \\
\text { contract. }\end{array}$ & 5.58 & 5.31 & 1.579 & .155 & $\begin{array}{l}\text { Accept Ho } \\
\text { p-value }=\geq 0.05\end{array}$ \\
\hline $\begin{array}{l}\text { V38 } \\
\text { I see a contract as } \\
\text { expensive. }\end{array}$ & 5.35 & 5.09 & 1.336 & .182 & $\begin{array}{l}\text { Accept Ho } \\
\text { p-value }=\geq 0.05\end{array}$ \\
\hline $\begin{array}{l}\text { V39 } \\
\text { Pre-paid vouchers are } \\
\text { more flexible. }\end{array}$ & 5.82 & 5.70 & .716 & .474 & $\begin{array}{l}\text { Accept Ho } \\
\text { p-value }=\geq 0.05\end{array}$ \\
\hline $\begin{array}{l}\text { V40 } \\
\text { Acquiring pre-paid } \\
\text { vouchers is easy. }\end{array}$ & 6.15 & 6.06 & .697 & .486 & $\begin{array}{l}\text { Accept Ho } \\
\text { p-value }=\geq 0.05\end{array}$ \\
\hline $\begin{array}{l}\text { V41 } \\
\text { I find getting a contract } \\
\text { as being too } \\
\text { complicated. }\end{array}$ & 4.67 & 4.30 & 1.691 & .092 & $\begin{array}{l}\text { Accept Ho } \\
\text { p-value }=\geq 0.05\end{array}$ \\
\hline
\end{tabular}




\begin{tabular}{|l|l|l|l|l|l|}
\hline $\begin{array}{l}\text { V42 } \\
\text { Pre-paid vouchers have } \\
\text { more service options } \\
\text { than contracts. }\end{array}$ & 3.99 & 3.75 & 1.174 & .232 & $\begin{array}{l}\text { Accept Ho } \\
\text { p-value }=\geq 0.05\end{array}$ \\
\hline
\end{tabular}

All six variables were accepted for students with a monthly income below R500 and monthly income above R501 as the students attach the same preference for pre-paid versus contract, therefore $\mathrm{Ho}_{1}$ is accepted and $\mathrm{Ha}_{1}$ is rejected.

Level of agreement and disagreement:

- V37 - Both students with a monthly income up to R500 and monthly income of R501 and more indicate that they slightly agree that price will influence their choice between pre-paid vouchers and contract. This could be an indication that students are price sensitive.

- V38 - Students with a monthly income up to R500 and monthly income of R501 and more slightly agree that they see contract as more expensive. This means that students' perception of contract will influence their selection of such.

- V39 - Students with a monthly income up to R500 and monthly income of R501 and more slightly agree that they see pre-paid vouchers as more flexible. Contract subscription is thus seen as being to structured compared to pre-paid vouchers.

- V40 - Both students with a monthly income up to R500 and monthly income of R501 and more agree that acquiring pre-paid vouchers is easy. Due to the availability of pre-paid vouchers at a large number of different outlets, students might perceive it as easy to acquire.

- V41 - Students with a monthly income up to R500 and monthly income of R501 and more neither agree nor disagree that they find getting a contract as too complicated. This could be an indication that students are uncertain about the availability and how to acquire contact subscription.

- V42 - Students with a monthly income up to R500 and monthly income of R501 and more slightly disagree that pre-paid vouchers have more service options than contracts. This could be an indication that students see a contract subscription as better than pre-paid vouchers.

Table 2: t-Test results for students' (with a monthly income up to R500 and monthly income of R501 and more) status value of cellular phones.

\begin{tabular}{|l|l|l|l|l|l|}
\hline \multirow{2}{*}{$\begin{array}{l}\text { Description of } \\
\text { variable }\end{array}$} & \multicolumn{2}{|l|}{$\begin{array}{l}\text { Means } \\
(1: \text { Strongley disagree - } \\
7: \text { Strongley agree })\end{array}$} & $\begin{array}{l}\text { t-Test for Equality } \\
\text { of Means }\end{array}$ & $\begin{array}{l}\text { Hypotheses } \\
\text { testing }\end{array}$ \\
\cline { 2 - 5 } & $\begin{array}{l}\text { Below } \\
\text { R500 }\end{array}$ & $\begin{array}{l}\text { Above } \\
\text { R501 }\end{array}$ & t & Sig. & \\
\hline $\begin{array}{l}\text { V 43 To own a cellular } \\
\text { phone helps to advance } \\
\text { my social standing }\end{array}$ & 5.42 & 5.17 & 1.264 & .207 & $\begin{array}{l}\text { Accept Ho } \\
\text { p-value }=\geq 0.05\end{array}$ \\
\hline $\begin{array}{l}\text { V 44 Owing a cellular } \\
\text { phone shows } \\
\text { membership of a } \\
\text { particular group. }\end{array}$ & 3.07 & 3.08 & -.031 & .975 & $\begin{array}{l}\text { Accept Ho } \\
\text { p-value }=\geq 0.05\end{array}$ \\
\hline
\end{tabular}




\begin{tabular}{|l|l|l|l|l|l|}
\hline $\begin{array}{l}\text { V } 45 \text { Being seen with a } \\
\text { cellular phone indicates } \\
\text { social status }\end{array}$ & 3.42 & 3.34 & .366 & .714 & $\begin{array}{l}\text { Accept Ho } \\
\text { p-value }=\geq 0.05\end{array}$ \\
\hline $\begin{array}{l}\text { V } 46 \text { A cellular phone } \\
\text { helps me to be } \\
\begin{array}{l}\text { accepted by the social } \\
\text { group that I want to } \\
\text { belong to. }\end{array}\end{array}$ & 2.32 & 2.40 & -.448 & .655 & $\begin{array}{l}\text { Accept Ho } \\
\text { p-value }=\geq 0.05\end{array}$ \\
\hline
\end{tabular}

The four variables for students with a monthly income below R500 and monthly income above R501 indicate that students attach the same status value to cellular phones, therefore $\mathbf{H o}_{2}$ is accepted and $\mathbf{H a}_{2}$ is rejected.

Level of agreement and disagreement:

- V43 - Students with a monthly income up to R500 and monthly income of R501 and more slightly agree that to own a cellular phone helps to advance their social standing. It can therefore be concluded that cellular phones influence social status in a positive fashion.

- V44 -Both students with a monthly income up to R500 and monthly income of R501 and more slightly disagree that owning a cellular phone shows membership to a particular group.

- V45 - Students with a monthly income up to R500 and monthly income of R501 and more slightly disagree that being seen with a cellular phone indicates social status. This indicates that a cellular phone is not a status symbol.

- V46 - Students with a monthly income up to R500 and monthly income of R501 and more disagree that that cellular phones help them to be accepted by the social group that they want to belong to. It can therefore be assumed that cellular phones do not help students to be accepted by groups or indicate membership to a group.

Table 3: t-Test results for Students' (with a monthly income up to R500 and monthly income of R501 and more) perception of the relationship between network operator and service quality.

\begin{tabular}{|l|l|l|l|l|l|}
\hline \multirow{2}{*}{$\begin{array}{l}\text { Description of } \\
\text { variable }\end{array}$} & \multicolumn{2}{|l|}{$\begin{array}{l}\text { Means } \\
\text { (1:Strongley disagree - } \\
7: \text { Strongley agree) }\end{array}$} & $\begin{array}{l}\text { t-Test for Equality } \\
\text { of Means }\end{array}$ & $\begin{array}{l}\text { Hypotheses } \\
\text { testing }\end{array}$ \\
\cline { 2 - 5 } & $\begin{array}{l}\text { Below } \\
\text { R500 }\end{array}$ & $\begin{array}{l}\text { Above } \\
\text { R501 }\end{array}$ & $\mathbf{t}$ & Sig. & \\
\hline $\begin{array}{l}\text { V47 I find my network } \\
\text { operator to be effective } \\
\text { in service delivery. }\end{array}$ & 5.76 & 5.90 & -.934 & .351 & $\begin{array}{l}\text { Accept Ho } \\
\text { p-value }=\geq 0.05\end{array}$ \\
\hline $\begin{array}{l}\text { V48 The services } \\
\text { (voice mail, sms, etc.) } \\
\text { provided by my current } \\
\text { network operator are } \\
\text { easy to use. }\end{array}$ & 6.31 & 6.34 & -.277 & .782 & $\begin{array}{l}\text { Accept Ho } \\
\text { p-value }=\geq 0.05\end{array}$ \\
\hline
\end{tabular}




\begin{tabular}{|l|l|l|l|l|l|}
\hline $\begin{array}{l}\text { V49 My network } \\
\text { operator covers the } \\
\text { country as a whole. }\end{array}$ & 5.48 & 5.61 & -.719 & .473 & $\begin{array}{l}\text { Accept Ho } \\
\text { p-value }=0.05\end{array}$ \\
\hline $\begin{array}{l}\text { V50 High price for } \\
\text { cellular calls is an } \\
\text { indication of the high } \\
\text { quality service from a } \\
\text { network operator for } \\
\text { me. }\end{array}$ & 3.42 & 3.10 & 1.672 & .095 & $\begin{array}{l}\text { Accept Ho } \\
\text { p-value }=\geq 0.05\end{array}$ \\
\hline $\begin{array}{l}\text { V51 I never experience } \\
\text { problems with my } \\
\text { network operator }\end{array}$ & 4.19 & 4.09 & .450 & .653 & $\begin{array}{l}\text { Accept Ho } \\
\text { p-value }=\geq 0.05\end{array}$ \\
\hline $\begin{array}{l}\text { V52 My network } \\
\text { operator is seen as a } \\
\text { high quality operator in } \\
\text { my social group. }\end{array}$ & 4.63 & 4.75 & -.622 & .543 & $\begin{array}{l}\text { Accept Ho } \\
\text { p-value }=\geq 0.05\end{array}$ \\
\hline
\end{tabular}

The six variables for students' (with a monthly income below R500 and monthly income above R501) perception of the relationship between network operator and service quality is the same therefore $\mathrm{Ho}_{3}$ is accepted and $\mathrm{Ha}_{3}$ is rejected.

Level of agreement and disagreement:

- V47 - Students with a monthly income up to R500 and monthly income of R501 and more indicate that they slightly agree that their network operator is effective in service delivery.

- V48 - Students with a monthly income up to R500 and monthly income of R501 and more agree that the services provided by their current network operator are easy to use.

- V49 - Students with a monthly income up to R500 and monthly income of R501 and more indicate that they slightly agree that their network operator covers the country as a whole.

- V50 - Both students with a monthly income up to R500 and monthly income of R501 and more slightly disagree that the high prices for cellular calls are an indication of high quality service from network operators for them. This could indicate that price is not a good indicator of quality to students.

- V51 - Students with a monthly income up to R500 and monthly income of R501 and more indicate that they neither agree nor disagree that they never experience problems with their network operator.

- V52 - Students with a monthly income up to R500 and monthly income of R501 and more neither agree nor disagree that their network operator is seen as high quality in their social groups. This could indicate that the network operator that students belong to is important in their social situation. 
Table 4: t-Test results for students' (with a monthly income up to R500 and monthly income of R501 and more) perception of the relationship between brand name and the quality of cellular phones.

\begin{tabular}{|l|l|l|l|l|l|}
\hline \multirow{2}{*}{$\begin{array}{l}\text { Description of } \\
\text { variable }\end{array}$} & \multicolumn{2}{l|}{$\begin{array}{l}\text { Means } \\
\text { (1:Strongley disagree - }\end{array}$} & \multicolumn{2}{l|}{$\begin{array}{l}\text { t-Test for Equality } \\
\text { of Means }\end{array}$} & $\begin{array}{l}\text { Hypotheses } \\
\text { testing }\end{array}$ \\
\cline { 2 - 6 } & $\begin{array}{l}\text { Below } \\
\text { R500 }\end{array}$ & $\begin{array}{l}\text { Above } \\
\text { R501 }\end{array}$ & t & Sig. & \\
\hline $\begin{array}{l}\text { V53 I am very satisfied } \\
\text { with my current brand's } \\
\text { quality. }\end{array}$ & 5.89 & 6.04 & -1.080 & .281 & $\begin{array}{l}\text { Accept Ho } \\
\text { p-value }=\geq 0.05\end{array}$ \\
\hline $\begin{array}{l}\text { V54 I find it easy to use } \\
\text { the different functions } \\
\text { of my current brand. }\end{array}$ & 5.90 & 6.18 & -2.221 & .027 & $\begin{array}{l}\text { Reject Ho } \\
\text {-value }=<0.05\end{array}$ \\
\hline $\begin{array}{l}\text { V55 My cellular phone } \\
\text { is seen as the leading } \\
\text { brand in terms of } \\
\text { quality. }\end{array}$ & 5.42 & 5.71 & -1.711 & .088 & $\begin{array}{l}\text { Accept Ho } \\
p \text {-value }=\geq 0.05\end{array}$ \\
\hline $\begin{array}{l}\text { V56 The type of cellular } \\
\text { phone that I own fits my } \\
\text { current needs. }\end{array}$ & 5.65 & 5.57 & .482 & .630 & $\begin{array}{l}\text { Accept Ho } \\
\text {-value }=\geq 0.05\end{array}$ \\
\hline $\begin{array}{l}\text { V57 I feel that my } \\
\text { cellular phone has too } \\
\text { many features I do not } \\
\text { use. }\end{array}$ & 3.78 & 3.58 & .964 & .336 & $\begin{array}{l}\text { Accept Ho } \\
p \text {-value }=\geq 0.05\end{array}$ \\
\hline
\end{tabular}

One of the variables for students' (with a monthly income below R500 and monthly income above R501) perception that the relationship between brand name and the quality of cellular phones is the same was rejected and four accepted, therefore $\mathbf{H o}_{23}$ is accepted and $\mathbf{H a}_{23}$ is rejected.

Level of agreement and disagreement:

- V53 - Students with a monthly income up to R500 slightly agree and students with a monthly income of R501 and more agree that they are very satisfied with their current brand's quality.

- V54 - Students with a monthly income up to R500 slightly agree that it is easy to use the different functions on their current brand of cellular phone. Students with a monthly income of R501 and more agree with this statement. The functions that current cellular phone brands have are satisfactory although it could be that students will want more functions as they become available.

- V55 - Students with a monthly income up to R500 and monthly income of R501 and more indicate that they slightly agree that their cellular phone brand is seen as the leading brand in terms of quality. This could indicate that the brand name of the cellular phone is important and it could mean that students will stay brand loyal.

- V56 - Students with a monthly income up to R500 and monthly income of R501 and more slightly agree that the type of cellular phone that they own fits their current needs. 
- V57 - Students with a monthly income up to R500 and monthly income of R501 and more indicate that they slightly disagree that their cellular phone does not have too many features they do not use.

\section{FINDINGS}

Pricing in the telecommunication industry is complicated as a large number of channel members, services and products are made available to consumers. Because of the large number of channel members setting prices and most of the cellular telecommunication industry not making public how they set prices, the researcher refers to possible price-setting methods that can used and explores their implication on the cellular telecommunication industry. In this paper, it is established that there is no significant difference between the two income groups regarding: preferences attached to pre-paid and contract; status value attached to cellular phones; perception of the relationship between network operator and service quality; and perception of the relationship between brand name and the quality of cellular phones. Since the findings indicate that there are no differences between the two income groups, strategies used in the student market will be the same for both these groups. However, on the level of agreement and disagreement, specific differences do exist.

Regarding students' preference of pre-paid versus contract, they indicated that price will influence their choice between pre-paid vouchers and contract, that they see contract as more expensive, that they see pre-paid vouchers as more flexible, and that acquiring pre-paid vouchers is easy. Students of both income groups indicate that they are uncertain whether getting a contract is too complicated. There is also an indication that students don't see pre-paid vouchers as having less service options than contracts.

With regards to status value of cellular phones, students indicated that to own a cellular phone helps to advance their social standing but does not show membership to a particular group, indicate social status, or that that cellular phones help them to be accepted by the social group that they want to belong to.

Students indicated, regarding the relationship between network operator and service quality, that their network operator is effective in service delivery and that the services provided by their current network operator are easy to use. They also indicated that their network operator covers the country as a whole. Students do however feel that the high prices for cellular calls are not an indication of high quality service from network operators. There is uncertainty whether they never experience problems with their network operator or that their network operator is seen as high quality in their social groups.

Regarding the relationship between brand name and the quality of cellular phones, students indicated that they are very satisfied with their current brand's quality, especially students with higher income. Students also indicated that it is easy to use the different functions on their current brand of cellular phone, that their cellular phone brand is seen as the leading brand in terms of quality, and that the type of cellular phone that they own fits their current needs. Students also indicated that their cellular phone does not have too many features they do not use.

\section{CONCLUSIONS AND RECOMMENDATIONS}

Although cellular phones are not seen as status symbols, students do see them as enhancing their social standing. Therefore, cellular phone manufacturers should promote their products as instruments that could increase a person's social standing. As students are satisfied with their existing cellular phones, manufacturers should maintain their efforts to preserve this perception. Students do not regard it as necessary to enter into contracts as a subscription method - network operators should consider the importance of this in terms of the student market. Should it be seen as sufficiently important, the process of getting a contract should be made easier and more customer friendly. Contracts could be positioned in a more flexible manner. This could be done in the form of contracts over different subscription time periods and by making it easier to change the type of contract. Network operators should maintain their current service delivery to customers. By providing the best possible customer service, switching could be 
prevented. Students, however, do not easily switch between network operators. Possible problems that were experienced in the past should be determined. The price of services should also be researched more extensively. Since price has an influence in the selection of pre-paid vouchers above contract, network operators could consider creating contract packages that could be controlled by the students themselves. The process of getting a contract could be revised. Given that students use most functions on their phones, cellular phone manufacturers could increase the complexity of functions for the youth, for example, by adding challenging features specifically for students.

\section{REFERENCES}

Arnould E, Price L \& Zinkhan G. 2004. Consumers. $2^{\text {nd }}$ Ed. Boston: McGraw - Hill.

Bakewell C \& Mitchell V. 2003. Generation Y female consumer decision-making styles. International Journal of Retail \& Distribution Management, 31(2):95-106.

Cant MC, Brink A \& Brijball S. 2006. Consumer Behaviour. Cape Town: Juta.

Cant MC \& Machado R. 2005. Marketing Success Stories. $5^{\text {th }}$ Ed. Cape Town: Oxford.

Churchill GA. 2001. Basic Marketing Research. $4^{\text {th }}$ Ed. Mason: South-Western.

Claasen L. 2001. Retailers look forward to better year. Business Day, 1.

Dillon WR, Madden TJ \& Firtle NH. 1994. Marketing research in a Marketing environment. $3^{\text {rd }}$ Ed. Burr Ridge: Irwin.

Economist. 1999. At the back of beyond. In. Economist.com [Online] Available from: http://ww w.economist.com/surveys/displayStory_id $=246216$ [Accessed: 25/01/2005].

Gilbert D, Kelly L \& Barton M. 2003. Technophobia, gender influences and consumer decision-making for technology-related products. European Journal of Innovation Management, 6(4):253-263.

Hair JF, Bush RP \& Ortinau DJ. 2000. Marketing Research - A practical approach for the new millennium. $7^{\text {th }}$ Ed. Boston: Irwin \& McGraw-Hill.

Hawkins DI, Best RJ \& Coney KA. 2001. Consumer Behaviour: Building Marketing Strategy. $8^{\text {th }}$ Ed. Boston: Irwin.

Kshetri N \& Cheung MK. 2002. What Factors are Driving China's Mobile Diffusion. Electronic Markets, 12(1):22-26.

Joubert M. 2000. Catch them when they're young. Financial Mail [Online] Available from: http://wunv.fm.co.za/00/033 1/focus/efocus.htm [Accessed: 14/08/2001].

Kinnear TC \& Taylor JR. 1996. Marketing Research: An applied approach. $5^{\text {th }}$ Ed. New York: McGrawHill, Inc.

Kotler P. 2003. Marketing Management. $11^{\text {th }}$ Ed. Upper Saddle River: Pearson Prentice Hall.

Kress K, Ozawa N \& Schmid G. 2000. The new consumer emerges. Strategy \& Leadership, 28(5):4-9.

Laroche M, Saad G, Cleveland M \& Browne E. 2000. Gender differences in information search strategies for Christmas gift. Journal of consumer marketing, 17(6):500-524. 
Malhotra NK. 2004. Marketing Research: An applied orientation. $4^{\text {th }}$ Ed. New Jersey: Pearson Education International.

Martin CA \& Bush AJ. 2000. Do role models influence teenagers purchase intentions and behaviours? Journal of Consumer Marketing, 17(5):441-454.

Martin B \& Marshall R. 1999. "The interaction of message framing and felt involvement in the context of cell phone commercials. European Journal of Marketing, 33(2):206-218.

McDaniel C Jr. \& Gates R. 2005. Marketing research. $6^{\text {th }}$ Ed. Danvers: John Wiley \& Sons, Inc.

Minges M, Männistö L \& Kelly T. 1999. Inform...the future is bright, the future is mobile. Info, 1(6):485496.

Morhange G \& Fontela E. 2003. Mobile communication from voice to data. Info, 5(2):24-33.

Mutula SM. 2002. The cellular phone economy in the SADC region: implications for libraries. Online Information Review, 26(2):79-92.

Pakola J, Pietilä M, Svento R \& Karjaluoto H. 2003. An investigation of consumer behaviour in mobile markets in Finland. $32^{\mathrm{ND}}$ EMAC Conference.

Parker RS, Hermans CM \& Schaefer AD. 2004. Fashion consciousness of Chinese, Japanese and American Teenagers. Journal of Fashion Marketing and Management, 8(2):176-186.

Reid FJM \& Reid DJ. 2004. Text appeal: the psychology of SMS texting and its implications for design of mobile phone interfaces. Campus-Wide Information Systems, 2(5):196-200.

Selian AN. 2004. Mobile Phones and Youth: A look at the US student market. International Telecommunication Union, 5-31.

Shiffman LG \& Kanuk LL. 2000. Consumer Behavior. $7^{\text {th }}$ Ed. London: Prentice Hall.

Solomon MR. 2004. Consumer Behavior. $6^{\text {th }}$ Ed. London: Prentice Hall.

Spero I \& Stone M. 2004. Agents of change: how young consumers are changing the world of marketing. Qualitative Market Research: An International Journal, 7(2):153-159.

Srivastava L. 2004. Japan's ubiquitous mobile information society. Info, 14(4):234-251.

Strydom J, Joost C \& Cant M. 2000. Marketing Management. $4^{\text {th }}$ Ed. Cape Town: Juta.

Tustin DH, Ligthelm AA, Martins JH \& Van Wyk H. 2005. Marketing Research in practice. Pretoria: Unisa Press.

Vrechopoulos AP, Constantiou ID \& Sideris I. 2002. Strategic marketing planning for mobile commerce diffusion and consumer adoption. In: Proceedings of the First International Conference on Mobile Business: Evolution Scenarios for Emerging Mobile Commerce Services - M-Business.

Ward P \& Sturrock F. 1998. "She knows what she wants...": towards a female consumption risk reducing strategy framework. Marketing Intelligence \& Planning, 16(5):327-336. 
UNESCO. 1998. Tertiary Enrolment Data [Online] Available from:

www.tfne.net/report/download/table\%20B.pdf [Accessed: 04/10/1998]. 